\title{
.8. СОВЕРШЕНСТВОВАНИЕ УПРАВЛЕНИЯ ДОХОДАМИ РЕГИОНАЛЬНЫХ БЮДЖЕТОВ В РОССИЙСКОЙ ФЕДЕРАЦИИ
}

\author{
Алешин Д.В., студент,
}

Финансового-экономический факультет

\author{
ФГОБУ ВО «Финансовый университет при Правительстве РФ», г. Москва
}

В статье представлены результаты проведенного анализа структуры и динамики доходов региональных бюджетов в Российской Федерации с выявлением доминирующих факторов, повлиявших на их формирование. На основе авторского подхода осуществлена классификация российских регионов с учетом рисков по отношению к устойчивому развитию субъектов РФ. Дано обоснование использования теории вероятностей при бюджетном планировании и прогнозировании. Исследование базируется на большом количестве собранных эмпирических данных Федерального казначейства, Министерства фринансов РФ, Федеральной службы государственной статистики.

\section{Литература}

1. Альгин А.П. Риск и его роль в общественной жизни [Текст] / А.П. Альгин. - М., 1989. - 189 с.

2. Балынин И.В. Комплексная модель оценки рисков несбалансированности бюджетов субъектов Российской Федерации в контексте социально-экономического развития регионов [Текст] / И.В. Балынин // Аудит и финансовый анализ. 2014. - №3. - С. 316-319.

3. Балынин И.В. Рейтинговая оценка субъектов Российской Федерации по уровню риска несбалансированности региональных бюджетов (на основе разработанной модели) [Текст] / И.В. Балынин // РИСК: Ресурсы, инфрормация, снабжение, конкуренция. - 2014. - №3. - С. 104-109.

4. Бушмин Е.В. Государственные и муниципальные доходы как составная часть бюджетной системы Российской Федерации [Текст] / Е.В. Бушмин. - М. : РЭУ им. Г.В. Плеханова, 2012. - 518 с.

5. Knight F. Risk, Uncertainty and Profit [Текст] / F. Knight. - Illinois: University of Illinois at Urbana-Champaign's Academy for Entrepreneurial Leadership Historical Research Reference in Entrepreneurship, 2009. - 382 c.

6. Евстратов Р.М. Неопределенность, вероятность, действие как главные составляющие предпринимательского риска [Текст] / Р.М. Евстратов // Основы экономики, управления и права. - 2014. - №1. - С. 58-61.

7. Маркина Е.В. Методология оценки влияния экономической неопределенности на формирование доходов региональных бюджетов [Текст] / Е.В. Маркина, О.В. Полякова, А.С. Ложечко // Экономика региона. - 2019. - Т. 15. - №3. - С. 924-937.

8. Официальный портал государственных услуг Ненецкого автономного округа [Электронный ресурс]. - Режим доступа: http://adm-nao.ru/.

9. Пешкова Х.В. Бюджетное устройство России [Текст] / под ред. Х.В. Пешковой. - М.: ИНФРА-М, 2014. - 175 с.

10. Сергиенко Н.С. Администрирование доходов бюджетов: проблема невыясненных поступлений [Текст] / Н.С. Сергиенко // Аудит и финансовый анализ. - 2017. - №2. - С. 228-232.

11. Сергиенко Н.С. Актуальные проблемы администрирования доходов бюджетов [Текст] / Н.С. Сергиенко // Налоги и налогообложение. - 2017. - №6. - С. 1-13.

12. Советское финансовое право [Текст] : учеб. / под ред. В.В. Бесчеревных, С.Д. Цыпкина. - М., 1982. - 464 с.

13. Социально-экономические проблемы современной российской экономики [Текст] : монография / под общ. ред. Н.А. Адамова. - М. : Ин-т исследования товародвижения и конъюнктуры оптового рынка, 2013. - 512 с.

14. Федеральное казначейство [Электронный ресурс] : официальный сайт. - Режим доступа: http://roskazna.ru/.

\section{Ключевые слова}

Бюджет; государственные доходы; налоговые доходы; налог на прибыль; бюджетное планирование и прогнозирование; риски; устойчивое развитие.

\section{Алешин Дмитрий Вячеславович}

\section{РЕЦЕНЗИЯ}

Актуальность темы обусловлена необходимостью перехода к эффективному и ответственному управлению доходами региональных бюджетов в целях обеспечения экономического роста и повышения качества жизни населения. Данный вопрос приобретает особую актуальность в условиях несбалансированности региональных бюджетов, высокого уровня государственного долга и одновременно большом объеме вопросов и задач, поставленных перед субъектами Российской Федерации.

Д.В. Алешин достаточно подробно изучил существующие в теории и практике общественных финансов подходы к толкованию государственных доходов, что позволило сформировать надежную основу для последующего анализа. Эмпирическая часть исследования базируется на официальных данных Министерства финансов РФ, Федерального казначейства, Федеральной службы государственной статистики.

Д.В. Алешиным проведен глубокий анализ в рамках изучения вопроса совершенствования управления доходами региональных бюджетов, на основе которого не только определена динамика и структура доходов бюджетов субъектов РФ, но и определены фракторы, оказывающие на влияние на их формирование. В заключительной части работы предложены пути решения выявленных проблем. Отдельно автор обращает внимание на проблему обеспечения эффективной борьбы с теневым сектором экономики, существование которого оказывает негативное воздействие на объем доходов бюджетов бюджетной системы РФ.

Значимость проведенного научного исследования заключается в возможности использования полученных результатов фринансовыми органами субъектов РФ, Федеральной налоговой службой РФ.

С учетом вышеизложенного, статья рекомендуется к опубликованию.

Сергиенко Н.С., к.э.н., доцент кафедры «Государственное и муниципальное управление» ФГОБУ ВО «Финансовый университет при Правительстве РФ», г. Москва.

DOI 10.38097/AFA.2020.94.57.017 
